\title{
Replacement Value of Cassava Peels with Rice Husk for Guinea Grass in the Diet of West African Dwarf (WAD) Sheep
}

\author{
M. I. Okoruwa ${ }^{1}$, F. U. Igene ${ }^{1} \&$ M. A. Isika ${ }^{2}$ \\ ${ }^{1}$ Department of Animal Science, Ambrose Alli University, Ekpoma, Edo-State, Nigeria \\ ${ }^{2}$ Department of Animal Science, University of Calabar, PMB 1115, Calabar, Nigeria \\ Correspondence: M. I. Okoruwa, Department of Animal Science, Ambrose Alli University, Ekpoma, Edo-State, \\ Nigeria. E-mail: odionokos@yahoo.com
}

\author{
Received: February 20, 2012 Accepted: March 5, 2012 Online Published: June 19, 2012 \\ doi:10.5539/jas.v4n7p254 URL: http://dx.doi.org/10.5539/jas.v4n7p254
}

\begin{abstract}
The study was conducted to determine the replacement value of cassava peels and rice husk combination for guinea grass, using nutrient digestibility, energy utilization and in vitro gas production characteristics by West African Dwarf Sheep. Fifteen (15) growing WAD Sheep with an average weight of $9.00 \pm 0.01 \mathrm{~kg}$ and aged between 9 and 10 months old were randomly assigned to three (3) dietary treatments with five (5) animals per treatment in a completely randomized design. The compared diets were A (guinea grass), B (cassava peels with rice husk in a ratio of 60:10) and $\mathrm{C}$ (cassava peels with rice husk in a ratio of 55:15). The results showed that parameters observed under digestibility, energy and in vitro gas production characteristics were significantly affected $(\mathrm{P}<0.05)$ with the exception of dry matter digestibility, gas produced from the soluble fraction $(\mathrm{a})$, gas production rate constant (c)and incubation time $\left(\mathrm{t}^{1} / 2\right)(\mathrm{P}>0.05)$. CP (74.37\%), EE (62.49\%), CF (47.08\%), ash (70.89\%), NDF (48.62\%), ADF (49.68\%), ADL (54.83\%) digestibility, GE intake (2229.74kcal/g/day), DE (95.45kcal/g/day), $\mathrm{CH}_{4}(13 \mathrm{ml}), \mathrm{ME}(8.31 \mathrm{MJ} / \mathrm{kg} / \mathrm{DM}), \mathrm{OMD}(56.10 \%)$ and SCFA $(0.09 \mu \mathrm{M})$ were significantly $(\mathrm{P}<0.05)$ better for diet $\mathrm{A}$. Gas production from the insoluble fraction $(38.75 \mathrm{ml})$ and potential gas production $(41.00 \mathrm{ml})$ were highest in diet B, whereas NFE digestibility $(79.38 \%)$, total energy output $(197.21 \mathrm{kcal} / \mathrm{g} / \mathrm{day})$ and metabolizable energy $\mathrm{BW}^{0.75}(15.11 \mathrm{kcal} / \mathrm{g} /$ day $)$ were higher for diet $\mathrm{C}$. It is concluded that cassava peels with rice husk in a ratio of 60:10 has a potential to replace guinea grass in the diet of WAD sheep.
\end{abstract}

Keywords: cassava peels, rice husk, digestibility, energy, in vitro gas production, sheep

\section{Introduction}

The survival of sheep and goats under harsh tropical environment together with their efficiency in feeds conversion, variety of feeds on which they can subsist and their relative resistance to diseases are some of the important characteristics responsible for profitable sheep rearing by rural populace. It has been observed that with all the afore-mentioned potentials of small ruminants, shortage of animal protein still remains a major problem confronting the ever increasing human population in the developing countries (Salami et al., 2010). Hence the problem of shortage of animal protein for human population can be overcome to a larger extent if sheep and goat rearing is done with scientific nutrition practices. One of the major factors contributing to this insufficiency in animal protein for human consumption in Nigeria and other developing countries is inadequate nutrition in small ruminants (Ahamefule \& Udo, 2010). The situation becomes worse during the dry season when ruminant animal are unable to meet their protein and energy requirement from available poor quality herbage with consequent marked weight loss and low productivity (Nigele et al., 2010). This inability of ruminant livestock producers to feed their animals adequately throughout the year is a major constraint in meeting future demands for meat and milk. To mitigate this problem of inadequate nutrition in small ruminants, the need to continuous searching for various alternative feeds that are less competitive for their use by man and other livestock could perhaps be one of the intervention areas needed to augment small ruminants production (Adewumi \& Ajayi, 2010). Consequently, animal nutritionists use unconventional feed resources such as agro-industrial wastes which are cheap, locally available and meet the nutritional requirements for livestock.

Cassava (Manihot esculenta crantz) peels and rice (Oryza sativa) husk are industrial wastes that can be extensively evaluated as alternative feeds for small ruminants. Cassava peel is a by-product of cassava tuber with valuable potentials as an alternative energy source for ruminants in many parts of the humid tropics. Though it is 
rich in energy, it contains low protein and toxic hydrogen cyanide $(\mathrm{HCN})$ which can affect its nutritive value for ruminants. However, the effect of this toxic substance can be reduced or completely eliminated through the use of various detoxification methods such as drying and fermentation (Wapat, 2003). Rice husk is a by-product of rice milling. Presently, it is of little or no economic value but environmental nuisance for small ruminant feeding under intensive system of productions. Limiting factors in its utilization in livestock feeds include high silica/ash content and abrasive characteristics which lead to low nutrient digestibility (Aderolu et al., 2007). However, there is paucity of information regarding the combination of cassava peels with rice husk as alternative energy source in sheep diet. Hence the objective of this study was to measure nutrient digestibility, energy utilization and in vitro gas production characteristics of diets of West African Dwarf Sheep, in which guinea grass was replaced by a combination of cassava peels and rice husk.

\section{Materials and Methods}

\subsection{Study Area}

The experiment was conducted at the Teaching and Research Farm, Ambrose Alli University, Ekpoma, Edo State, Nigeria. The study area was located within longitude $6.09^{\circ} \mathrm{E}$ and $6.42^{\circ} \mathrm{N}$ with an average annual rainfall of about $1556 \mathrm{~mm}$. The mean annual minimum and maximum temperature were about $26^{\circ} \mathrm{C}$ and $34^{\circ} \mathrm{C}$ respectively.

\subsection{Experimental Diet's Preparation}

Experimental diets were prepared for the trial (basal and supplementary diets). Guinea grass and a combination of cassava peels and rice husk were used as basal diets. Guinea grass was harvested from a pasture land within the Teaching and Research Farm, it was allowed to wilt overnight before being chopped manually using matechet to a length of approximately $3-4 \mathrm{~cm}$. Cassava peels and rice husk were collected from their processing points located within Ekpoma metropolis and sun-dried. Cassava peels were washed before they were sun-dried separately from rice husk. Concentrate supplement ingredients were purchased in Benin and the formulation consisted of the following; $80 \%$ wheat offal, $18 \%$ brewery dried grain, $0.75 \%$ limestone, $0.5 \%$ bone meal, $0.5 \%$ salt and $0.25 \%$ vitamin premix. Three experimental diets (A, B and C) were prepared which were given to the animals at 5\% (dry matter basis) of their body weight in the ratio of 70:30 respectively. The control group which was diet A constituted guinea grass as basal diet, while diets B and C comprised combination of cassava peels with rice husk in a ratio of 60:10 and 55:15 respectively. Concentrate supplement diet was served to all the animals in the diets.

\subsection{Experimental Animals, Feeding and Management}

Fifteen (15) growing WAD ram lambs were purchased from weekly markets within Ekpoma. The experimental animals weighing between 8.01 to $10.01 \mathrm{~kg}$ had an average weight of $9.01 \mathrm{~kg}$. The trial lasted for 12 weeks after a 14-day adjustment period of animals to the experimental diets. Animals were treated against ecto and endo parasites during the adjustment period. Treatments were repeated on the $6^{\text {th }}$ week of the trial using the same drugs as a precautionary measure against micro-organism infections. The experimental pens were cleaned and disinfected before animals were later allotted to individual pens. Diets were offered once daily at $08.00 \mathrm{hrs}$ with supplement first, followed by the basal diets. Water and salt lick were provided for each animal ad libitum.

\subsection{Digestibility and Energy Utilization Trials}

Four (4) West African Dwarf Sheep per treatment (totaling 12) were randomly allocated to the three dietary treatments in metabolic crates fitted with facilities for separate collection of urine and faeces. The quantity of feed offered and left over as well as faeces and urine were determined by weighing daily for seven (7) days after a 7-day adjustment period. Representative samples of faeces and urine were stored in a deep freezer until required for analysis. Hence apparent nutrient digestibility was calculated using this formula:

$$
\text { Apparent Nutrient Digestibility }=\frac{\text { nutrient Intake }- \text { Nutrient in Faeces }}{\text { Nutrient Intake }} \times 100
$$

Heat combustion of feeds, faeces and urine were determined using an adiabatic bomb calorimeter. Digestible Energy (DE) and Metabolizable Energy (ME) intake per animal were determined from the energy content of the feeds intake and the amount of energy through faeces, urine and methane. The amount of energy loss through methane was set at $4-5 \%$ of the gross energy intake (CSIRO, 2001).

\subsection{Chemical Analysis and in Vitro Gas Production Procedures}

Proximate composition of feeds and faeces were determined according to AOAC (1990) and detergent fibre fractions by the methods of Van Soest et al (1991). 
Rumen liquors were obtained from the rumen of animals previously fed with the three (3) experimental diets which were used for the gas production study. About $200 \mathrm{mg}$ of dry milled sample i.e cassava peels and rice husk combination in a ratio of 60:10 was used as the standard substrate. The sample was replicated three times for each treatment and placed into $100 \mathrm{ml}$ graduated gas tight plastic syringes. Incubation was carried out at $39 \pm 1^{0} \mathrm{C}$ which lasted for $24 \mathrm{hrs}$ as described by Menke and Staingass, (1988). At post incubation period, $4 \mathrm{ml}$ of $\mathrm{NaOH}$ $(10 M)$ was introduced to estimate methane production following the method described by Fievez et al (2005). Data were obtained on volume of gas and methane $\left(\mathrm{CH}_{4}\right)$ produced. Metabolisable energy (ME) and Organic Matter Degradability (OMD) were estimated (Menke \& Steingass, 1988). Short Chain Fatty Acids (SCFA) were calculated as reported by Getachew et al (2003). The equation $\mathrm{Y}=\mathrm{a}+\mathrm{b}\left(1-\mathrm{e}^{-\mathrm{ct}}\right)$ was used to estimate gas production characteristics (Akinfemi et al., 2009).

Where $\mathrm{Y}=$ volume of gas produced at time $\mathrm{t}$,

$\mathrm{a}=$ intercept (gas produced from the soluble fraction)

$\mathrm{b}=$ gas production from the insoluble fraction

$\mathrm{c}=$ gas production rate constant for the insoluble fraction (b)

$\mathrm{t}=$ incubation time

$$
\begin{gathered}
\mathrm{a}+\mathrm{b}=\text { potential gas production } \\
\mathrm{ME}=2.2+0.136 * \mathrm{GV}+0.0057 * \mathrm{CP}+0.0002865 * \mathrm{EE}^{2} \\
\mathrm{OMD}=14.88+0.889 * \mathrm{GV}+0.0448 * \mathrm{CP}+0.0651 * \mathrm{XA} \\
\mathrm{SCFA}=0.0239 * \mathrm{GV}-0.0601
\end{gathered}
$$

Where GV, CP, EE and XA were net gas production ( $\mathrm{ml} / 200 \mathrm{mg} \mathrm{DM})$, crude protein, ether extract and ash of the incubated samples respectively.

Experimental Design and Statistical Analysis: The experimental animals were randomly allotted to three (3) dietary treatments in a completely randomized design.

Data obtained were subjected to one-way analysis of variance (ANOVA). Significant differences between means were separated by Duncan Multiple Range Test (SAS, 1997).

\begin{tabular}{|c|c|c|c|c|}
\hline \multirow[b]{2}{*}{ Composition } & \multicolumn{3}{|c|}{ Basal Diets } & \multirow{2}{*}{$\begin{array}{c}\text { Concentrate Supplement } \\
\text { CSP }\end{array}$} \\
\hline & GGS & CPL & RHK & \\
\hline $\mathrm{DM}$ & 26.00 & 78.40 & 91.03 & 82.42 \\
\hline $\mathrm{CP}$ & 7.95 & 5.25 & 3.25 & 20.78 \\
\hline $\mathrm{EE}$ & 4.00 & 6.37 & 10.00 & 2.06 \\
\hline $\mathrm{CF}$ & 31.00 & 23.62 & 18.50 & 14.00 \\
\hline Ash & 8.00 & 7.77 & 40.50 & 8.02 \\
\hline NFE & 48.15 & 56.99 & 27.75 & 55.44 \\
\hline NDF & 74.30 & 68.48 & 70.00 & 67.00 \\
\hline $\mathrm{ADF}$ & 42.70 & 47.41 & 50.00 & 24.00 \\
\hline $\mathrm{ADL}$ & 13.87 & 14.22 & 19.05 & 9.02 \\
\hline GE (kcal/g) & 3.89 & 3.44 & 2.48 & 2.02 \\
\hline
\end{tabular}

\section{Results and Discussions}

\subsection{Dry Matter and Chemical Composition of Diets}

Table 1. Chemical Composition (\% DM basis) of basal and supplementary diets

GGS $=$ Guinea grass, $\overline{\mathrm{CPL}}=$ cassava peels, $\mathrm{RHK}=$ Rice husk, $\mathrm{CSP}=$ Concentrate supplement

Presented in Table 1, is the dry matter and chemical composition of the basal and concentrate supplement diets used in the feeding trail. Dry matter (DM) values for diets were quite high with exception of guinea grass (GGS) that was low. The higher DM content implied the ability to accumulate more nutrients. Typically, the three basal 
diets (Guinea grass, Cassava peels and Rice husk) were deficient in crude protein (CP) but rich in crude fibre (CF) and therefore could not be fed to promote production in sheep without appropriate supplementation. Hence, concentrate supplement (CSP) was included in diets to provide fermentable carbohydrate and nitrogen to augment the supply of nutrients from the basal diets and encourage rumen degradation (Yousuf \& Adeoye, 2011). Values for CP and ADF were in agreement with earlier reports (F.A.O, 2003) for guinea grass. Moreover, the CP value recorded for CSP in this study satisfied the ARC (1984) recommendation of $113 \mathrm{~g} / \mathrm{CP} / \mathrm{kg}$ diet for growth in ruminant animals. Ether extract (EE) and ash values recorded in rice husk (RHK) were higher than values for guinea grass (GGS), cassava peels (CPL) and concentrate supplement (CSP). Nitrogen free extract (NFE) for diets were high and varied from 27.75 to $56.99 \%$. Gross energy (GE) values ranged from 2.02 to $3.89 \mathrm{kcal} / \mathrm{g}$. The value of $2.48 \mathrm{kcal} / \mathrm{g}$ observed for rice husk (RHK) was in agreement with earlier reports by Aderolu et al (2007). The results of the fibre fraction in the diets shows that neutral detergent fibre (NDF), acid detergent fibre (ADF) and acid detergent lignin (ADL) were quiet high. It has been reported by Bakshi and Wadhwa (2004) that high levels of NDF and ADL have negative effect on DM intake and digestibility but increase ruminal rate of passage in ruminants.

\subsection{Apparent Nutrient Digestibility}

Table 2. Apparent nutrient digestibility (\%)of WAD sheep fed experimental diets

\begin{tabular}{|c|c|c|c|c|}
\hline \multirow{2}{*}{ Nutrients } & \multicolumn{3}{|c|}{ Diets } & \multirow{2}{*}{$\mathrm{SEM}_{+}$} \\
\hline & $\mathrm{A}$ & B & $\mathrm{C}$ & \\
\hline Dry matter & 61.92 & 60.86 & 62.94 & 1.61 \\
\hline Crude protein & $74.37^{\mathrm{a}}$ & $70.93^{b}$ & $65.68^{\mathrm{c}}$ & 0.08 \\
\hline Ether extract & $62.49^{\mathrm{a}}$ & $55.27^{\mathrm{b}}$ & $56.07^{\mathrm{b}}$ & 0.01 \\
\hline Crude fibre & $47.08^{\mathrm{a}}$ & $36.16^{\mathrm{b}}$ & $34.77^{\mathrm{b}}$ & 0.01 \\
\hline Ash & $70.89^{\mathrm{a}}$ & $66.15^{\mathrm{b}}$ & $68.07^{\mathrm{b}}$ & 0.51 \\
\hline Nitrogen free extract & $69.12^{\mathrm{b}}$ & $72.94^{\mathrm{b}}$ & $79.38^{\mathrm{a}}$ & 1.89 \\
\hline Neutral detergent fibre & $48.62^{\mathrm{a}}$ & $40.74^{\mathrm{b}}$ & $38.20^{\mathrm{b}}$ & 0.02 \\
\hline Acid detergent fibre & $49.68^{\mathrm{a}}$ & $47.58^{\mathrm{b}}$ & $43.36^{\mathrm{b}}$ & 0.00 \\
\hline Acid detergent lignin & $54.83^{\mathrm{a}}$ & $46.64^{b}$ & $43.77^{\mathrm{b}}$ & 0.04 \\
\hline
\end{tabular}

The apparent nutrient digestibility of West African Dwarf Sheep fed experimental diets is shown in Table 2. DM digestibility values were not significantly affected $(\mathrm{P}>0.05)$ by dietary treatments. The non significant differences observed could be attributed to the general high DM content of the diets. (60.86-62.94\%) recorded in this study which were not in conformity with the ranged values $(46-77.25 \%)$ for Yankasa Sheep earlier reported by Ngele et al (2010). Crude protein $(\mathrm{CP})$ digestibility was significantly affected $(\mathrm{P}<0.05)$ across dietary treatments. Animals on diet A (74.37\%) was significantly highest, followed by B $(70.93 \%)$ and C $(65.68 \%)$ was the least.The gradual decrease in the trend of $\mathrm{CP}$ digestibility as the level of cassava peels decreased with increase in the level of rice husk inclusion in diets could be associated with low CP content and poor degree of nutrient utilization. The $\mathrm{CP}$ digestibility values obtained in the present study were not in consonance with the finding of Adewumi and Ajayi (2010) whose values ranged between 28.50 and 32.50\% for WAD Sheep fed full fat neem fruit and corn bran. Ether extract (EE), crude fibre $(\mathrm{CF})$ and ash showed no significant differences $(\mathrm{P}>$ $0.05)$ between diets $\mathrm{B}$ and $\mathrm{C}$ but diet $\mathrm{A}$ was significantly $(\mathrm{P}<0.05)$ higher than diets $\mathrm{B}$ and $\mathrm{C}$. Values for $\mathrm{EE}$ and ash ranged from 55.27 to $62.49 \%$ and 66.15 to $70.89 \%$ respectively. The higher EE and ash digestibility values recorded for animals in all the diets implied that the diets were more effective in improving the utilization of EE and ash. The apparent crude fibre digestibility values of $47.08,36.16$ and $34.77 \%$ were obtained for diets A, B and $\mathrm{C}$ respectively. The decrease in CF digestibility as the inclusion level of test basal materials increased in the diet could probably be due to the increase in fibre content of the test materials. This confirms the report of Jokthan et al (2010) that the fibre of a feed has great influence on its digestibility. Nitrogen free extract (NFE) varied significantly $(\mathrm{P}<0.05)$ among diets with animals on diet $\mathrm{C}(79.38 \%)$ being significantly highest, followed 
by B (72.94\%) and A (69.12\%). The higher NFE digestibility values observed in all the diets could be an indication of better proportion of energy sources in the experimental diets that were appropriate to enhance energy. The neutral detergent fibre (NDF) and acid detergent fibre and lignin (ADF \& ADL) followed a similar trend with $\mathrm{CF}$ digestibility. This implied that fibre fraction digestibility in the diets $\mathrm{A}$ and $\mathrm{B}$ were better and improved microbial activity in the rumen. Hence, information on CF and fibre fraction contents of a diet is essential for the assessment on their digestibility (Njidda \& Ikhimioya, 2010).

The general low $\mathrm{CP}, \mathrm{CF}$ and fibre fraction digestibility of animals on diet $\mathrm{C}$ might be attributed to the higher percentage of rice husk content in the diet that could sub-optimally reduce rumen degradability or low microbial activity in the rumen (Aderolu et al., 2007). The comparatively high nutrient digestibility of animals on diets A and $\mathrm{B}$ associated with zero to low percentage of rice husk content in the diets, that could probably be attributed to the gradual solubility of the diets, thereby making nutrients available over a long period of time which enhances rumen microbial activity (Oddoye et al., 2005). Studies on digestibility are therefore said to be important as they allow the estimation of nutrients really available for animal performance (Okoruwa \& Adewumi, 2010).

\subsection{Energy Utilization}

Table 3. Replacement value of cassava peels with rice husk for guinea grass on energy utilization of WAD sheep (kcal/g/day)

\begin{tabular}{|c|c|c|c|c|}
\hline \multirow{2}{*}{ Parameters } & \multicolumn{3}{|c|}{ Diets } & \multirow{2}{*}{$\mathrm{SEM}_{+}$} \\
\hline & A & $\mathrm{B}$ & $\mathrm{C}$ & \\
\hline Gross energy intake & $2229.74^{\mathrm{a}}$ & $1761.47^{\mathrm{b}}$ & $1407.71^{\mathrm{c}}$ & 5.56 \\
\hline Gross energy intake $\mathrm{BW}^{0.75}$ & $324.48^{\mathrm{a}}$ & $271.90^{\mathrm{b}}$ & $229.82^{\mathrm{c}}$ & 3.62 \\
\hline Total energy output & $190.35^{\mathrm{b}}$ & $172.56^{\mathrm{c}}$ & $197.21^{\mathrm{a}}$ & 0.38 \\
\hline Digestible energy & $95.45^{\mathrm{a}}$ & $94.21^{\mathrm{a}}$ & $90.01^{\mathrm{b}}$ & 0.71 \\
\hline Metabolizable energy $\mathrm{BW}^{0.75}$ & $3.91^{\mathrm{c}}$ & $11.24^{\mathrm{b}}$ & $15.11^{\mathrm{a}}$ & 0.88 \\
\hline
\end{tabular}

a, b, c means on the same row with different superscripts are significantly different $(\mathrm{P}<0.05)$.

Table 3, shows results for energy utilization of WAD Sheep fed experimental diets. Significant differences $(\mathrm{P}<0.05)$ were observed across the dietary treatments. Gross Energy $(\mathrm{GE})$ intake was significantly $(\mathrm{P}<0.05)$ higher in animals on diet A $(2229.74 \mathrm{kcal} / \mathrm{g} /$ day $)$ followed by diet B $(1761.47 \mathrm{kcal} / \mathrm{g} /$ day $)$ and diet $\mathrm{C}$ $(1407.71 \mathrm{kcal} / \mathrm{g} /$ day). The progressive decrease in GE intake across diets in response to increase in inclusion level of rice husk could probably be due to abrasive characteristics of rice husk. This is in conformity with the earlier reports of Aderolu et al (2007) that abrasive characteristics of rice husk affect intake and digestibility negatively. The GE intake in $\mathrm{BW}^{0.75}$ followed similar pattern as the GE intake assessed. The estimated total energy losses values were $190.35,172.56$ and $197.21 \mathrm{kcal} / \mathrm{g} /$ day for diets A, B and C respectively. The significant lower $(\mathrm{P}<$ 0.05 ) value of total energy losses obtained in animals on diet $B$ could be attributed to low faeces voided and balance utilization of nutrient compared to diets $\mathrm{A}$ and $\mathrm{C}$. The range of values obtained in this study were lower than the one (123.50 to $289.53 \mathrm{kcal} / \mathrm{g} /$ day) earlier reported by Bawala and Akinsoyinu (2002). Digestible energy (DE) was not significantly $(\mathrm{P}>0.05)$ influenced by diets $\mathrm{A}$ and $\mathrm{B}$ but diet $\mathrm{C}$ was significantly $(\mathrm{P}<0.05)$ different from diets $\mathrm{A}$ and $\mathrm{B}$. The low value observed in animals on diet $\mathrm{C}(90.01 \mathrm{kcal} / \mathrm{g} / \mathrm{day})$ compared with diets A $(95.45 \mathrm{kcal} / \mathrm{g} / \mathrm{day})$ and B $(94.21 \mathrm{kcal} / \mathrm{g} /$ day $)$ could probably be explained by reduction in feed intake and imbalance levels of nutrient utilization caused by anti nutritional factors as reported by Okoruwa and Adewumi (2010). Values in the present study were higher than the DE range of values (2.4 to $2.6 \mathrm{Mcal} / \mathrm{kg} / \mathrm{day}$ ) as earlier reported by Jose et al (2010) but lower than average value of $134.06 \mathrm{kcal} / \mathrm{g} /$ day as reported by Calegare et al (2007). Significant differences $(\mathrm{P}<0.05)$ were observed for estimated metabolizable energy $(\mathrm{ME})$ in $\mathrm{BW}^{0.75}$ among dietary treatments. The significant low values observed in animals on diet A (3.91 kcal $/ \mathrm{g} / \mathrm{day})$ compared with diet B $(11.24 \mathrm{kcal} / \mathrm{g} /$ day $)$ and $\mathrm{C}(15.11 \mathrm{kcal} / \mathrm{g} /$ day $)$ might be as a result of high energy loss through urine and methane. The estimated values were higher than the mean value of $3.80 \mathrm{kcal} / \mathrm{g} / \mathrm{day} \mathrm{DM}$ earlier reported by Johnson et al (2003), hence metabolizble energy requirements play a vital role in determining the performance of small ruminant animals. 


\subsection{In Vitro Gas Production}

Table 4. In vitro gas production ( $\mathrm{ml} / 200 \mathrm{mg} \mathrm{DM})$ characteristics of a standard substrate in rumen liquors of WAD sheep fed experimental diets ( 24 hours)

\begin{tabular}{lllll}
\hline \multirow{2}{*}{ Parameters } & \multicolumn{4}{c}{ Rumen liquor from diets } \\
\cline { 2 - 4 } & \multicolumn{1}{c}{ A } & \multicolumn{1}{c}{$\mathrm{B}$} & \multicolumn{1}{c}{$\mathrm{C}$} & \\
\hline $\mathrm{a}(\mathrm{ml})$ & 1.29 & 2.25 & 1.54 & 0.31 \\
$\mathrm{~b}(\mathrm{ml})$ & $23.12^{\mathrm{b}}$ & $38.75^{\mathrm{a}}$ & $20.44^{\mathrm{b}}$ & 0.82 \\
$\mathrm{a}+\mathrm{b}(\mathrm{ml})$ & $25.00^{\mathrm{b}}$ & $41.00^{\mathrm{a}}$ & $22.00^{\mathrm{b}}$ & 1.94 \\
$\mathrm{c}\left(\mathrm{mlh}^{-1}\right)$ & 0.07 & 0.05 & 0.05 & 0.01 \\
$\mathrm{t}^{1} / 2(\mathrm{hr})$ & 10.51 & 9.00 & 12.50 & 2.40 \\
$\mathrm{CH}_{4}(\mathrm{ml})$ & $13.00^{\mathrm{a}}$ & $10.00^{\mathrm{b}}$ & $11.00^{\mathrm{b}}$ & 0.45 \\
$\mathrm{ME}(\mathrm{MJ} / \mathrm{Kg} / \mathrm{DM})$ & $8.31^{\mathrm{a}}$ & $6 . .92^{\mathrm{b}}$ & $9.72^{\mathrm{a}}$ & 0.19 \\
$\mathrm{OMD}(\%)$ & $56.10^{\mathrm{a}}$ & $46.71^{\mathrm{c}}$ & $49.81^{\mathrm{b}}$ & 1.39 \\
$\mathrm{SCFA}(\mu \mathrm{M})$ & $0.99^{\mathrm{a}}$ & $0.75^{\mathrm{b}}$ & $0.82^{\mathrm{a}}$ & 0.05 \\
\hline
\end{tabular}

$\mathrm{CH}_{4}=$ Methane, $\mathrm{ME}=$ Metabolizable energy, OMD $=$ Organic matter, SCFA $=$ Short Chain Fatty Acids.

a,b,c Means on the same row with different superscript are significantly different $(\mathrm{P}<0.05)$.

Table 4 shows the in vitro gas production characteristics of a standard substrate when incubated in rumen liquors from animals fed experimental diets for $24 \mathrm{hrs}$. Significant differences $(\mathrm{P}<0.05)$ were observed for all the parameters assessed except gas production from soluble fraction (a), rate constant of gas production (c) and incubation time $\left(\mathrm{t}^{1 /}\right)$ that were not significant $(\mathrm{P}>0.05)$. The significant variation $(\mathrm{P}<0.05)$ observed for gas production from the insoluble fraction (b), the potential gas production from the insoluble fraction (b) and the potential gas production $(\mathrm{a}+\mathrm{b})$ were higher in diet $\mathrm{B}(38.75$ and $41.00 \mathrm{ml})$ compared with diet A $(23.12$ and $25.00 \mathrm{ml})$ and diet C (20.44 and $22.00 \mathrm{ml})$. Cerillo and Juarez (2004), indicated that the intake of a feed is mostly explained by the rate of gas production which affects the rate of passage of the feed through the rumen, whereas the potential gas production $(a+b)$ is associated with the degradability of the feed. Therefore, the higher values obtained for $(a+b)$ in diet B might indicate a better nutrient availability for rumen microbes. Hence, potential gas production is a function of inherent factors in rumen, which were different for all animals (Arigbede et al., 2006). It is important to note that methane production was least by the rumen liquor obtained from animals fed diet $\mathrm{B}$ reflecting methanogenesis that was obviously suppressed and translated to a more efficient utilization of the diet. It was reported by Babayemi and Bamikole (2006) that methane gas is an important gas among gases produced by ruminants during fermentation which have negative correlation with energy utilization and growth performance in ruminants. The low significant $(\mathrm{P}<0.05)$ values observed in $\mathrm{ME}(6.92 \mathrm{MJ} / \mathrm{kg} / \mathrm{DM}), \mathrm{OMD}$ $(46.71 \%)$ and SCFA $(0.75 \mu \mathrm{M})$ for rumen liquor obtained from animals fed diet B, suggests the presence of non-methanogenic fibre degrading microbes, hence a mutual relationship exist between total methane gas production and ME and OMD by Aganga and Mosase (2001).

\section{Conclusion}

This study supports the notion that agro-industrial wastes are excellent sources of basal diets in the off season, hence a combination of cassava peels and rice husk in a ratio of 60:10 has the potential to replace guinea grass as basal diet in ruminant animals without adversely affecting growth performance and activities of rumen microbes.

\section{References}

Aderolu, A. Z., Iyayi, E. A., \& Onilude, A. A. (2007). Changes in nutritional value of rice husk during Trichoderma viride degradation. Bulgarian Journal of Agricultural Science, 13, 583-589.

Adewumi M. K., \& Ajayi, D. A. (2010). Replacement value of full fat neem fruit for corn bran in the diet of West African Dwarf (WAD) Sheep. Proc. $35^{\text {th }}$ conf. Nig. Sec. for Anim. Prod. Univ of Ibadan, Nigeria. pp. 591-593.

Aganga, A. A., \& Mosase, K. W. (2001). Tannin content, nutritive value and dry matter digestibility of Lonchocarpus cassa, Zizyphus mucronata, Scherocarya birrea, KIrkia acuminate and Rhus lancea seeds. Anim. Feed sci. Technol, 91, 107-113. http://dx.doi.org/10.1016/S0377-8401(01)00235-8 
Ahamefule, F. O., \& Udo, M. D. (2010). Performance of West African Dwarf Goats fed raw or processed pigeon pea (Cajanus cajan) seed meal based diets. Nig. J. Anim. Prod., 37(2), 227-236.

Akinfemi, A., Adesanya, A. O., \& Aya, V. E. (2009). Use of an in vitro gas production technique to evaluate som Nigerian feedstuffs. American - Eurasian Journal of scientic Research, 4(4), 240 -245.

AOAC. (1990). Official Methods of Analysis (Association of Official Analytical Chemists) $14^{\text {th }}$ edition, Washington DC. pp. 141.

ARC. (1984). Agricultural Research Council. The nutrient requirements of livestock. Commonwealth. Agricultural Bureaux, Slough, England.

Arigbede, O. M, Anele, U. Y., Olanite, J. A., Adekunle, I. O., Jolaosho, O. A., \& Onifade, O. S. (2006). Seasonal in vitro gas production parameters of three multipurpose tree species in Abeokuta, Nigeria. Livestock Reseach for Rural Development, 18(10), 18142.

Babayemi. O. J., \& Bamikale, M. A. (2006). Effect of Tephrosia candida DC leaf and its mixtures with guinea grass on in vitro fermentation changes as feed for ruminants in Nigeria. Pakistan Journal of Nutrition, 5(1), 14-18. http://dx.doi.org/10.3923/pjn.2006.14.18

Bakshi, M. P. S., \& Wadhwa, M. (2004). Evaluation of forest leaves of semi-hilly arid region as livestock feed. Asian-Australian J. Anim. Sc., 95, 93-104.

Bawala, T. O., \& Akinsoyinu, A. O. (2002). Nutritional evaluation of browsers, GlyricidiaI sepium and Ficus thoningii foliage in goat diet: 2 Energy utilization and requirement. Proc. $7^{\text {th }}$ Ann. Conf. Anim. Sci. Ass. of Nig. (ASAN), Univ. of Agric. Abeokuta, Nigeria. pp 174-176.

Calegare, L., Alencar, M. M., Packer, I. U., \& Lanna, D. P. D. (2007). Energy requirements and cow/calf efficiency of Nellore, continental and British Bos Taurus x Nellore crosses. J. Anim. Sci, 85, 2413- 2422. http://dx.doi.org/10.2527/jas.2006-448

Cerillo, M. A., \& Juarez, R. A. S. (2004). In vitro gas production parameters in cacti and tree species commonly consumed by grazing goats in a semiarid region of North Mexico. Livestock Reseach for rural development, 16(4), 16021.

CSIRO. (2001). Testing Sheep for Methane production. Science Image, CSIRO Division, GA 1334.

FAO (Food and Agricultural Organization of the United Nations). (2003). Guinea Grass Colonial grass. Tanganyika grass. http://www.fao.org/ag/agapo/fog/AFRIS/DATA/118.HTM

Fievez, V., Babayemi, O. J., \& Demeyer, D. (2005). Estimation of direct and indirect gas production in syringes: A tool to estimate short chain fatty acid production requiring minimal laboratory facilities. Journal of Animal Feed Science, 86, 168-175.

Getachew, G., Robinson, P. H., DePeters, E. J., \& Taylor, S. J. (2003). Relationship between chemical composition, dry matter degradation and in vitro gas production of several ruminant feeds. Animal feed science and technology, 3, 57-71.

Johnson, D. E, Ferrell, C. L., \& Jenkins, T. G. (2003). The history of energetic efficiency research: where have we been and where are we going. J.Anim. Sci., 55, 1190-1199.

Jokthan, G. E., Braimah, Y., Muhammed, I. R., Abdu, S. B., \& Mohammed, R. H. (2010). Evaluation of the performance of Yankasa sheep fed Acacia sayel Del (Chenchilo) pod as replacement for cotton seed cake. Nigeria .J. Anim .Sci. (Formerly Tropical Journal of Anim Sci.), 12, 129-140.

Jose, V. C. M, Juan, C. K., \& Juan, G. M. (2010). Estimation of metabolizable energy requirements for maintenance and energetic efficiency of weight gain in Bos Taurus and Bos indicus cows in Tropical Mexico. Journal of Animal and Veterinary Advances, 9, 421-428. http://dx.doi.org/10.3923/javaa.2010.421.428

Menke, K. H., \& Steingass, H. (1988). Estimation of the energetic feed value from chemical analysis and in vitro gas production using rumen fluid. Animal Research and Development, 28, 47-55.

Ngele, M. B, Adegbola, T. A., Bogoro, S. E. F, Abubakar, M., \& Kalla, D. J. U. (2010). Nutrient intake, digestibility and growth performance of Yankasa sheep fed urea -treated or untreated rice straw with supplement. Nig. J. Anim. Prod., 37(1), 61-70.

Njidda, A. A., \& Ikhimioya, I. (2010). Nutritional evaluation of some semi-arid Browse forages leaves as feed for goats. European Journal of Applied Sciences, 2(3), 108-115. 
Oddoye, E. O., Amaning-Kwarteng, K., Awotwi, E. K., \& Fleischer, J. E. (2005). In Sacco degradability of grass and hay and rumen characteristics in sheep fed urea ammoniated rice straw or untreated supplemented rice straw. Bulletin of Animal Health and Production for Africa, 53(2), 113-123. http://dx.doi.org/10.4314/bahpa.v53i2.32697

Okoruwa, M. I., \& Adewumi, M. K. (2010). Effect of replacing Panicum maximum with dried pineapple pulp on nutrient digestibility and nitrogen balance of WAD sheep. Nigerian J. Anim. Sci. (Formerly Tropical Journal of Animal Science), 12, 103-109.

Salami, S. O., Makinde, F. A., \& Garba, G. M. (2010). Foetal wastage in goats slaughter in Zaria abattoir, Northern Guinea Savanna Zone of Nigeria. Nig. J. Anim Prod., 37(1), 117-122.

SAS. (1997). Statistical Analysis System. SAS User's Guide. Cary, Ny SAS institute.

Van Soest, P. J., Robertson, J. B., \& Lewis, B. A. (1991). Methods for dietary Fibre, neutral detergent fibre and non-starch polysaccharides in relation to animal nutrition. J. Dairy Sci., 74, 3583-3597. http://dx.doi.org/10.3168/jds.S0022-0302(91)78551-2

Wanapat, M. (2003). Manipulation of cassava cultivation and utilization to improve protein to energy biomass for livestock feeding in the tropics. Asian Aust. J. Anim. Sci., 16, 463-472.

Yousuf, M. B., \& Adeloye, A. A. (2011). Performance response of goats fed shed leaves (Vitellaria paradoxa, Gmelina arborea and Daniella oliveri) based diets. Nig. J. of Anim. Prod., 38(1), 99-105. 